\title{
The prevalence of nursing mouth caries of preschool children
}

\author{
Rine Dianegianty*, Inne Suherna Sasmita*, Arlette Suzy Puspa Pertiwi Setiawan* \\ *Department of Pedodontics, Faculty of Dentistry, Padjadjaran University
}

\begin{abstract}
Introduction: Mouth Nursing caries is a particular form of dental caries in children and infants. Mouth Nursing Caries occurs in children aged of 2-4 years old and attack the primary maxillary anterior teeth, maxillary and mandibular first primary molar and primary canine mandibular. Nursing caries Mouth happens because of the habit of falling asleep while sucking a bottle containing sweet liquids (baby formula) in a prolonged period. This research aimed to determine the number and the prevalence of preschool children suffering from nursing mouth caries at Cimahi. Methods: The research method was descriptive with survey technique. Samples selected by cluster random sampling technique consisted of 13 kindergartens with 315 preschool children as the total sample. Results: The result shows that 234 or 74 preschool children. $3 \%$ have nursing mouth caries and the rest of 81 preschool children or $27.5 \%$ do not have nursing mouth caries. Conclusion: This research concludes that the prevalence of Nursing Mouth caries in preschool children at Cimahi in 2012 is $74.3 \%$ or 3/4 of the number of samples Examined.
\end{abstract}

Keywords: NMC, Preschool, Prevalence

\section{INTRODUCTION}

Indonesian public awareness of oral health still lacks due to a lack of socialization on oral health from an early age. Lack of parental knowledge about their oral hygiene will cause caries in children. Caries can not only occur in adults, but even children and toddlers may also occur.

The existence of Dental and Oral Health Month National organized by the Faculty of Dentistry, the University of Padjadjaran in the last two years has motivated people who are less concerned about the health of your teeth and mouth. Caries is the occurrence of a cavity on any tooth surface due to the development of plaque in the mouth during a specific time. ${ }^{1}$ Caries is an infection of the teeth resulting in calcified tissue damage and outages locally. It is essential to understand that the cavity on the surface of teeth is a sign of bacterial infection. ${ }^{2}$

The process of caries affected by tooth surface, carbohydrates, and bacteria. Process of decay begins with the demineralization on the outer surface of the tooth because of the formation of organic acids during the fermentation of bacterial carbohydrate diet. Initially, the new lesion will appear as opaque white dots; with progressive loss of tooth tissue and eventually become a cavity. ${ }^{1}$ Sutardjo revealed in the daily newspaper Suara Merdeka 2010 that the results of the Basic Health Research in 2007 are $72.1 \%$ of Indonesia's population affected by caries. ${ }^{3}$ Even in the last 12 months $23.4 \%$ of the Indonesian population complained of oral and dental 
problems. Still, only $29.6 \%$ were looking for help and health care personnel. National Health and Nutrition Examination Survey III (NHANES III) indicate that the prevalence of caries in primary teeth aged $2-11$ years is $42 \% .^{4}$

Conducted a study of the prevalence of caries in children aged 3-4 years and compared the prevalence of the 311 children in 1991 and 517 children in 1999 . The results showed a $49 \%$ prevalence of caries in children in 1991 and 38\% in children in 1999. The prevalence of caries in children in 1999 is higher, especially in the anterior maxillary teeth. ${ }^{5}$

Mouth Nursing caries (NMC) or Early Childhood caries (ECC) is a particular form of caries in children and infants. It usually occurs in children 2-4 years and attacked the maxillary anterior primary teeth, the first molar deciduous teeth upper and lower jaws and canine mandible. This can happen because of the habit of falling asleep while sucking a bottle containing sugary liquids (formula) in the long term. ${ }^{5}$

The results obtained from 317 children aged 15 to 60 months at Cileunyi Bandung in June until August 2004 as many as 180 children (56.78\%) who experienced NMC. The prevalence is based on the frequency of brushing teeth once as much as $31.55 \%$ (100 children), twice as much as $23.03 \%$ (73 children), and three times as much as $2.2 \%$ (7 children). The survey from the National Health and Nutrition Examination III (NHANES III) resulted in $80 \%$ of patients with caries, $20 \%$ of children with low socioeconomic. ${ }^{4}$

There has been no specific research on the NMC or another oral disease, especially at preschool age on Early Childhood Education (ECD) Cimahi. Early Childhood Education (ECD) is education intended for pre-school aged children for children to develop their potential early on so that they can grow naturally according to their age and developmental. ${ }^{6}$

Cimahi has an area of $40.2 \mathrm{~km} 2$, according to Law No. 9 of 2001. Cimahi is divided into three districts, namely North Cimahi, Central Cimahi and South Cimahi. According to statistics in 2009 Cimahi, people who check their teeth and mouth to Hospital Mitra Kasih as much as 3,852 people, while to the Hospital Cibabat as many as 5,510 people. ${ }^{7}$ The research objective was to determine the number and the prevalence of preschoolers who experienced NMC in Cimahi.

\section{METHODS}

The type of research is descriptive with survey techniques to determine the prevalence of nursing mouth caries in preschool children at Cimahi.

The population in the study were all early childhood institutions in Cimahi spread over three districts and 14 villages as many as 215 ECD.

The sampling technique used in the study was random cluster sampling with population criteria, namely ECD in Cimahi, students that are registered are ECD aged at 2-5 years old, healthy male and female.

Sub-districts selected randomly by researchers to be the location of the sampling is North Cimahi subdistrict of four villages with 29 of early childhood education. ECD sampling of the population in the four villages used the Slovin formula to obtain 13 ECD of the sample. ${ }^{8}$

\section{RESULTS}

The study was conducted on 315 children aged two to five years by a random cluster sampling in 13 Early Childhood Education (ECD) District of North Cimahi. Clinical examination will be done on children in according to the pre-determined criteria.

The results showed 234 children have nursing mouth caries and 81 children do not have nursing mouth caries. The picture of the magnitude of the prevalence of child obtained by nursing mouth caries was $74.3 \%$ and the incidence of mouth nursing children without caries was $25.7 \%$. The results of the research can be seen in the table and diagram below.

The results showed that the majority gender of preschoolers in Cimahi in 2012 is females with a number of $176(55.9 \%)$ and the male are139 individuals (44.1\%) as shown in Table 1.The results showed that most preschoolers in Cimahi in 2012 aged five years old were 142 people (45.1\%), aged four years old were 130 people (41.3\%), aged three years old were 32 people $(10.2 \%)$ and two years old were 11 people $(3.5 \%)$ as shown in table 2 . The results showed that most of the preschoolers in Cimahi in 2012 with NMC as many as 234 people (74.3\%) and 81 people (25.7\%) without NMC as in 
Table 1. Frequency Distribution of Preschool Children in Cimahi in 2012 based on Gender

\begin{tabular}{ccc}
\hline Gender & Frequency & percent \\
\hline Male & 139 & 44.1 \\
Female & 176 & 55.9 \\
\hline Total & 315 & 100.0 \\
\hline
\end{tabular}

diagram 1.

In Table 3 note that of the 139 preschoolers males were 106 people (33.65\%) with NMC and 176 females preschoolers as much as 128 people (40.63\%) with NMC as shown in Table 3.

In Table 4 note that of among 11 preschoolers
Table 2. Frequency Distribution of Preschool Children in Cimahi in 2012 based on Age

\begin{tabular}{ccc}
\hline Age & Frequency & Percent \\
\hline 2 yrs & 11 & 3.5 \\
3 yrs & 32 & 10.2 \\
4 yrs & 130 & 41.3 \\
5 yrs & 142 & 45.1 \\
\hline Total & 315 & 100.0 \\
\hline
\end{tabular}

aged two years as many as six people (1.90\%) with NMC. From 32 preschool children aged three years as many as 21 people $(6.67 \%)$ with NMC. From 130 preschool children aged four years as

Diagram 1 Distribution Frequency Prevalence Number of Children Who Have Mouth Nursing caries in Cimahi in 2012.

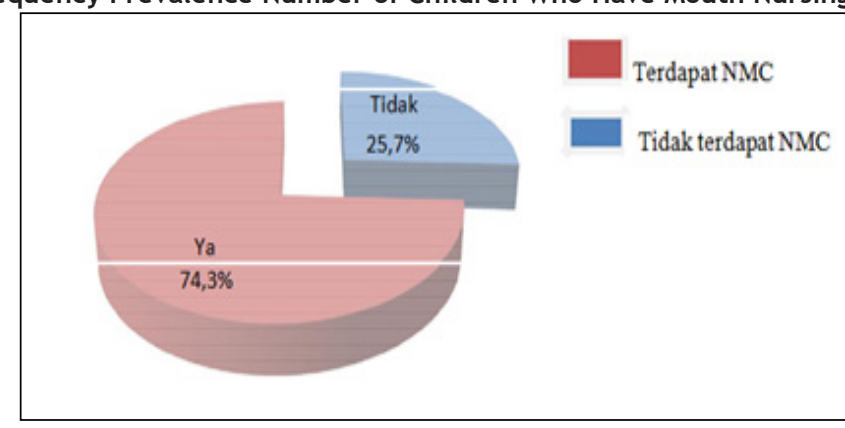

Table 3 Frequency Distribution Table 3 Prevalence of Preschool Children Experiencing Mouth Nursing caries in Cimahi in 2012

\begin{tabular}{cccccc}
\multicolumn{7}{c}{ based on Gender } & Total \\
\hline Gender & With & \multicolumn{5}{c}{ NMC } \\
\hline & Frequency & $\%$ & Frequency & $\%$ & 139 \\
\hline Male & 33 & $10: 48$ & 106 & 33.65 & 176 \\
Female & 48 & $15: 24$ & 128 & 40.63 & 315 \\
\hline Total & 81 & 25.71 & 234 & 74.29 &
\end{tabular}

many as 98 people (31.11\%) with NMC. From 142

people $(34.60 \%)$ with NMC as shown in Table 4. preschool children aged five years as many as 109

Table 4. Frequency Distribution Prevalence of Preschool Children Who Have Mouth Nursing caries in Cimahi in 2012 based on age

\begin{tabular}{|c|c|c|c|c|c|}
\hline \multirow{3}{*}{ Age } & \multicolumn{4}{|c|}{ NMC } & \multirow{3}{*}{ Total } \\
\hline & \multirow{2}{*}{$\begin{array}{c}\text { With } \\
\text { Frequency }\end{array}$} & \multicolumn{3}{|c|}{ Without } & \\
\hline & & $\% \%$ & Frequency & $\%$ & \\
\hline 2 years & 5 & $1: 59$ & 6 & 1.90 & 11 \\
\hline 3 years & 11 & $3: 49$ & 21 & 6.67 & 32 \\
\hline 4 years & 32 & $10: 16$ & 98 & 31.11 & 130 \\
\hline 5 years & 33 & $10: 48$ & 109 & 34.60 & 142 \\
\hline Total & 81 & 25.71 & 234 & 74.29 & 315 \\
\hline
\end{tabular}

\section{DISCUSSION}

Nursing mouth caries research is carried out on
315 samples at 13 ECD with 139 boys and 176 girls. The subject of the study consisted of 11 children aged two years, 32 children aged three years, 
130 children aged four years and 142 children aged five years. The prevalence of nursing mouth caries in preschool children in District 315 North Cimahi, Cimahi amounted to $74.3 \%$. It is quite large compared to the research conducted by Chemiawan (2004) in Village Cileunyi Wetan District of Bandung Regency by $56.78 \%$ due to the frequency of the toothbrush one sehari. ${ }^{9}$

Table 2 shows the percentage of the characteristics of preschool age in Cimahi among the group of children aged 2-5 years. Percentage of children aged two years is $3.5 \%$, three-years-old $10.2 \%$, four-year-olds is $41.3 \%$, and five-year-old is $45.1 \%$.

In table 4 shows that the prevalence of nursing mouth caries in Cimahi in preschool children is as high as 234 children (74.3\%) with experienced nursing mouth caries and as many as 81 children $(25.7 \%)$ without nursing mouth caries. It is also mentioned in the Kelly and Bruerd research conducted in 1989 that the prevalence of NMC in developing countries could reach up to $70 \% .{ }^{10}$

Kalra et al (2011) do research on the incidence of NMC in preschool children in Gurgaon, which reached $68.7 \% .{ }^{11}$ This can occur due to the habit of eating poor, poor oral hygiene, complicated children's emotions, and the frequency of sugary foods and drinks.

Said caries in preschool children in Lithuania are very well observed. ${ }^{12}$ In children aged three years, who experienced NMC is $50.6 \%$ due to the habit of drinking sweet liquid (formula) and rarely brushed their teeth. Almeida et al. (2000) said 33 children $(79 \%)$ of the 42 children suffered from NMC. ${ }^{13}$

Some factors contributing to the high prevalence of NMC in preschool children is consuming food and sugary drinks until fall asleep (McDonald, 2004). ${ }^{5}$ Preschool children who suffer from chronic diseases are often given drugs which contain sucrose syrup in an extended period, this can lead to nursing mouth caries. ${ }^{10}$

Sucrose in the form of sugar, when metabolized by bacteria to produce dextran which allows the bacteria attached to the tooth surface and will form plaques. The bacteria can cause a decrease in $\mathrm{pH}$ to 5.5. A decrease in $\mathrm{pH}$ to 5.5 is the demineralization of the tooth surface. ${ }^{1.2}$ Preschool children aged 1-5 years usually consume sugary drinks all night and daily sugar intake is a significant factor in the development of nursing mouth caries. ${ }^{10}$

Said that children who have consumed milk in a bottle NMC usually in children aged two years by $48 \%$ and in children aged three years as many as $39 \% .{ }^{15}$ The child consumed sweet foods or drinks 1-3 times per day. Besides, NMC also occur in children with socioeconomic level and low parental knowledge. ${ }^{16}$

Table 4 explains that the research results (40.63\%) of girls experienced nursing mouth caries more than boys (33.65\%). The prevalence of dental caries in girls are slightly higher than boys.

According to research the prevalence of caries in children aged 3-13 years $65.4 \%$ are girls. It is usually caused by the speed of tooth eruption in girls than boys and often consumes sweet food. ${ }^{18}$

Researched caries, there are 226 from 3,288 people got caries. ${ }^{19} \mathrm{~A}$ total of $8.8 \%$ of female and $4.5 \%$ of male with caries. It shows that the prevalence of caries in female more than male, due to several factors: 1 ) tooth eruption in female earlier than male, causing longer exposed to food cariogenic, 2) female are more frequent eats snacks, 3) pregnant and hormonal influences.

Table 5 illustrates that the research results of children who have nursing mouth caries at the age of two years as many as six people $(1.9 \%)$, the age of three years as are 21 people $(6.67 \%)$, the age of four years are 98 people $(31.11 \%)$, and the age of five years are 109 people (34.6\%).

From these results that many experienced nursing mouth caries are children at the aged of five. Tyagi said that the prevalence of nursing mouth caries in children aged 5-6 years amounted to $51.46 \%$ in Bangalore (Urban) due to lack of attention from parents and often consumed sweet foods every day and giving sugary drinks at night. ${ }^{20}$ The research says that the prevalence of nursing mouth caries in children aged five years is $55.4 \%$, but because of the imbalance sample size, the sample size of Children aged under five years less than that of children aged five years and usually children older little less cooperative in the investigation, and the emotional level is still high. ${ }^{10,21}$

NMC early prevention can be done by encouraging children to reduce the habit of drinking milk bottle, brushing teeth, drink using 
glasses for 12 months, consult a dentist as first teeth grow. Fluoride and antimicrobial agents containing chlorhexidine and thymol should be provided. ${ }^{13,15}$

\section{CONCLUSION}

Prevalence of nursing mouth caries in preschool children at Cimahi in the year 2012 was $74.3 \%$ or $3 / 4$ of the number of samples examined.

\section{REFERENCES}

1. Kidd E. Essential of Dental caries 3rd ed. Toronto: Oxford University Press. 2005.

2. Roberson M. Theodore. Operative Dentistry . 4th ed. St. Louis: Mosby International Limited. 2002.

3. Suara Merdeka. The Basic Health Research . UMM. 2010. 1-7. pp

4. Samour PQ, King K. Pediatric Nutrition 4th ed. London: Jones \& Bartlett. 2010.

5. MCDonald RE. Dentistry for the Child and Adolescent. Philadelphia: Mosby. 2004.

6. Permana AY. Early childhood education (ECD) in formal education: between expectations with reality. Architectural Engineering Department of Architectural Engineering Education FPTK UPI. 2010. 1-9 pp

7. Kep Badan Pus Statistik. The Central Bureau of Statistics Cimahi, Cimahi 2010. In Figures 2010. 24-63

8. Sugiyono. Methods. Bandung: CV Alphabeta. 2009

9. Chemiawan EE, Riyanti SN, Tjahyaningrum. Prevalence of nursing mouth caries in children aged 15-60 months based on the frequency of dental diseases in the village posyandu Cileunyi Cileunyi Wetan District of Bandung regency. 2004.

10. Vadiakas G. Case definition, etiology and risk assessment of Early Childhood caries (ECC): A revisited reviews. Euro Arc Ped Dent. 2008;9(3):114-125.

11. Kalra G, Bansal K, Sultan A. Prevalence of early childhood caries and assessment of its associated risk factors in preschool children of Urban Gurgaon, Haryana. Ind J Dent Sci. 2011;3(1):12-15.
12. Slabsinskiene E, Milciuviene S, Narbutaite J, Vasiliauskiene I. Severe early childhood caries and behavioral risk factors among 3-year-old children in Lithuania. Department of Oral Health and Pediatric Dentistry. 2010; 46(1):135141. DOI: $10.3390 /$ medicina 46020020

13. Almeida AG, Roseman MM. Future caries susceptibility in children with early childhood caries caries Following treatment under general anesthesia. American Academy of Pediatric Dentistry. 1999;22(4):302-306.

14. Slabsinskiene E. Severe early childhood caries and behavioral risk factors among 3-year-old children in Lithuania. Department of Oral Health and Pediatric Dentistry, 2010;46(1). 135-141.

15. Begzati A, Berisha M, Meqa K. Early childhood caries in preschool children of Kosovo- a serious public health problem.BMC Public Health. 2010;10(1):1- 8.

16. Oliveira LB, Sheiham A. Exploring the association of dental caries with social factors and nutritional status in Brazilian preschool children. European Journal of Oral Sciences 2008;116(1):37-43.

17. Finn SB. Clinical Pedodontics 4th ed. Philadelphia: WB Saunders. 2003

18. Singh RD, Khatter R. Prevalence of dental caries among the school going children of Amritsar city in relation of different associated factors. Indian Journal of Comprehensive Dental. 2011;1(1):25-29.

19. Lukacs, John R. Largaespada, Leah L. Explaining sex differences in the prevalence of dental caries: saliva, hormones, and "lifehistory" etiologies. American J Human Bio, Vol 2006;18(1):540-555

20. Kalra GK, Bansal A, Sultan. Prevalence of early childhood caries and assessment of its associated risk factors in preschool children of Urban Gurgaon, Haryana. Ind J Dent Sci. 2011; 3(1):12-15.

21. Behrman R, Kliegman R, Arvin A. Pediatrics. $2^{\text {th }}$ ed. Jakarta: EGC. 2011

22. Meyer F, Enax J. Eraly chilhood caries: Epidemiology, Aetiology, and Prevention. Int J Dent. Vol 2018. 7 pp. DOI: https://doi. org/10.1155/2018/1415873 